\title{
Impairment of Micronucleus and DNA in the 2-Chloro-4- Ethylamino-6- Isopropylamino-1, 3, 5-Triazine Exposed Poecilia Sphenops
}

\author{
Vasanth $\mathrm{S}^{1,2 *}$, Bupesh $\mathrm{G}^{1,2}, \mathrm{~T}$ Siva Vijayakumar ${ }^{2,3}$ and \\ Subramanian $\mathrm{P}^{2}$ \\ ${ }^{1}$ Research and Development Wing, Sree Balaji Medical College \& Hospital, India \\ ${ }^{2}$ Department of Animal Science, Bharathidasan University, India \\ ${ }^{3} \mathrm{PG} \&$ Research Department of Biotechnology, Srimad Andavan College of Arts \\ and Science, India
}

*Corresponding author: Vasanth S, Research and Development Wing, Sree Balaji Medical College \& Hospital, Chrompet, Chennai-600044, Tamil Nadu, India, E-mail: sakthivel.vasanth@gmail.com

\section{Research Article \\ Volume 1 Issue 2}

Received Date: November 30, 2017

Published Date: December 28, 2017

DOI: $10.23880 / \mathrm{hij}-16000112$

\section{Abstract}

The micronucleus and DNA fragmentation assays have been used progressively more to evaluate genotoxicity of many compounds in contaminated aquatic atmosphere. The objective of the current study was to investigate the genotoxic effect of 2-chloro-4-ethylamino-6- isopropylamino-1, 3, 5-triazine in Poecilia sphenops. Fish were exposed to atrazine $(2.5,1.25,0.83 \mu \mathrm{g} / \mathrm{L})$ and control also maintained simultaneously for 100 days. Erythrocyte and liver cells were sampled on 100 days of exposure for assessment of micronuclei induction in blood erythrocytes and DNA damage using single cell gel electrophoresis assay. Frequency of micronucleated erythrocytes in the peripheral blood cells with an increase in concentration of the atrazine were observed in treated fish. Comet assay revealed a significant DNA damage in treated atrazine. These findings may provide evidence for atrazine induced genotoxicity that could be useful for investigating the effects of toxic blooms on wild fish populations.

Keywords: DNA fragmentation; Micronuclei; Herbicides; Poecilia sphenops; Liver; Erythrocyte

Abbreviations: SCGE: Single-Cell Gel Electrophoresis; RAPD: Random amplification of polymorphic; DNA: Deoxyribonucleic acid

\section{Introduction}

There is a growing concern over the widespread use of herbicides that contaminate the aquatic environment. As a consequence of agriculture runoff, rains, irrigation waters, wetland applications, etc., herbicides are released into aquatic ecosystems.
Among the various herbicides used, atrazine (2-chloro4-ethylamino-6- isopropylamino-1, 3, 5-triazine), because of its high stability and persistence in the aquatic environment attracts special attention.

The DNA damage which is induced by atrazine exposure could be evaluated by using the comet assay $[1,2]$. The comet assay [alkaline single-cell gel electrophoresis (SCGE)] is a widely used technique to detect DNA damage due to environmental stress and has been used for the analysis of biomarkers of 
environmental pollution [3]. DNA from unexposed and arsenic-exposed liver cells exhibited distinct ladder indicating maximum DNA damage [4]. Arsenic can build apoptosis in neuroblastoma cells characterized by morphological changes and nucleo-somal DNA fragmentation [5]. The presence of different potent genotoxic substances in the aquatic environment has led to the development and adaptations of many modern and reliable techniques for quick monitoring. Random amplification of polymorphic DNApolymerase chain reaction (RAPD-PCR) is emerging as an important and useful method in the field of ecotoxicology studies [6]. Exposure to genotoxic agents can give rise to alterations of DNA structure that can lead to abnormal changes of DNA fingerprint.

The micronucleus assay in peripheral erythrocytes provides a probable approach to monitor the effects of environmental genotoxic agents in fish. The micronucleus assay in erythrocytes of fish was widely used as a marker for environment pollutant [7]. It has reported that using the micronucleus assays for genotoxicity studies [8]. In the present study, investigates the genotoxicity changes of micronucleus and DNA in the case of affected by 2-chloro-4ethylamino-6- isopropylamino-1, 3, 5-triazine herbicide on Poecilia sphenops.

\section{Material and Methods}

\section{Test Species}

Poecilia sphenops.

Live bearing Poecilia sphenops (Black molly) was chosen for this study.

Healthy Poecilia sphenops adult males were procured from the local aquarist. They were acclimatized for a maximum period of 15 days in the laboratory condition. The adult fishes with an average weight of $1.03 \pm 0.25 \mathrm{gm}$ and average length of $4.66 \pm$ $0.29 \mathrm{~cm}$ were used. Based on the $96 \mathrm{hrs}$ LC50 values, a set of 20 fish were then exposed to each of the three sub-lethal concentrations of the atrazine $(1.25,2.5$ and $5 \mathrm{~g} / \mathrm{L}$ ) for 100 days and used for the study. A set of 20 fish were also simultaneously maintained as control $(0 \mathrm{mg} / \mathrm{L})$.

\section{Sample Preparation for Micronucleus Test}

At the end of 100 days of atrazine exposure, Peripheral blood samples were obtained from the caudal vein of the Poecilia sphenops and smeared on clean slides. After fixation in pure ethanol for $20 \mathrm{~min}$, slides were kept to air-dry and then the smears were stained with $10 \%$ Giemsa solution for $25 \mathrm{~min}$.
Observations were made using an Olympus research microscope.

Five slides were prepared from each group of fish. Thousands erythrocytes were scored from each slide under 100- fold magnification to determine the frequency of notched nuclei, lobed nuclei, budding, fragmenting and also micronucleated cells, which was calculated as per 1000 cells (\%). NAs were classified according [9].

\section{Sample Preparation for DNA Fragmentation}

At the end of 100 days of exposure, Poecilia sphenops were dissected and liver, were dissected the obtained tissue samples homogenized with $200 \mu \mathrm{l}$ of homogenizing buffer using eppendorf and incubated at $55^{\circ} \mathrm{C}$. After incubation, the samples were centrifuged at $10,000 \mathrm{rpm}$ for 10 minutes. Transfer the supernatant to the fresh tube and added the phenol: chloroform: Isoamylalcohol in the ratio of 25:24:1. The mixture was gently inverted and centrifuged again at $12,000 \mathrm{rpm}$ for 15 Minutes. Transfer the supernatant to the fresh tube, mix with equal volume of $0.3 \mathrm{M}$ Sodium acetate and triple the volume of $100 \%$ ice cold ethanol. The mixture was stored at deep freezer for $30 \mathrm{~min}$. Again centrifuge the mixture at $14,000 \mathrm{rpm}$ for 30 minutes. Discard the supernatant. Wash the pellet with $100 \mu \mathrm{l}$ of $70 \%$ ethanol. Again centrifuge at $14,000 \mathrm{rpm}$ for 10 minutes. Discard the ethanol solution allow to air dry. The precipitated DNA was dissolved in $30 \mu \mathrm{l}$ of TE buffer and stored in deep freezer [10].

\section{Agarose Gel Electrophoresis}

Running the DNA in $0.8 \%$ agarose gel checked the purity of isolated DNA. Sample was loaded on the slot $0.8 \%$ agarose gel containing ethidium bromide. The electrophoresis was carried out until the dye migrate approximately $3-4 \mathrm{~cm}$ from the well. Purity also assessed by sharpness of the band and free from any companioned bands.

\section{Result}

The frequencies of micronuclei nuclear abnormalities are observed in erythrocytes of Poecilia sphenops exposed to atrazine. The frequencies of micronuclei, observed in erythrocytes of Poecilia sphenops, atrazine to the tested three sub lethal concentrations of the Atrazine herbicide showed differences among themselves. The kinds of the nuclear alterations (Figure $1 \& 2$ ) most frequently observed in erythrocytes of Poecilia sphenops exposed to the Atrazine are binucleated cells, cells with "blebbed" nuclei, cells along with "lobed" nuclei. 

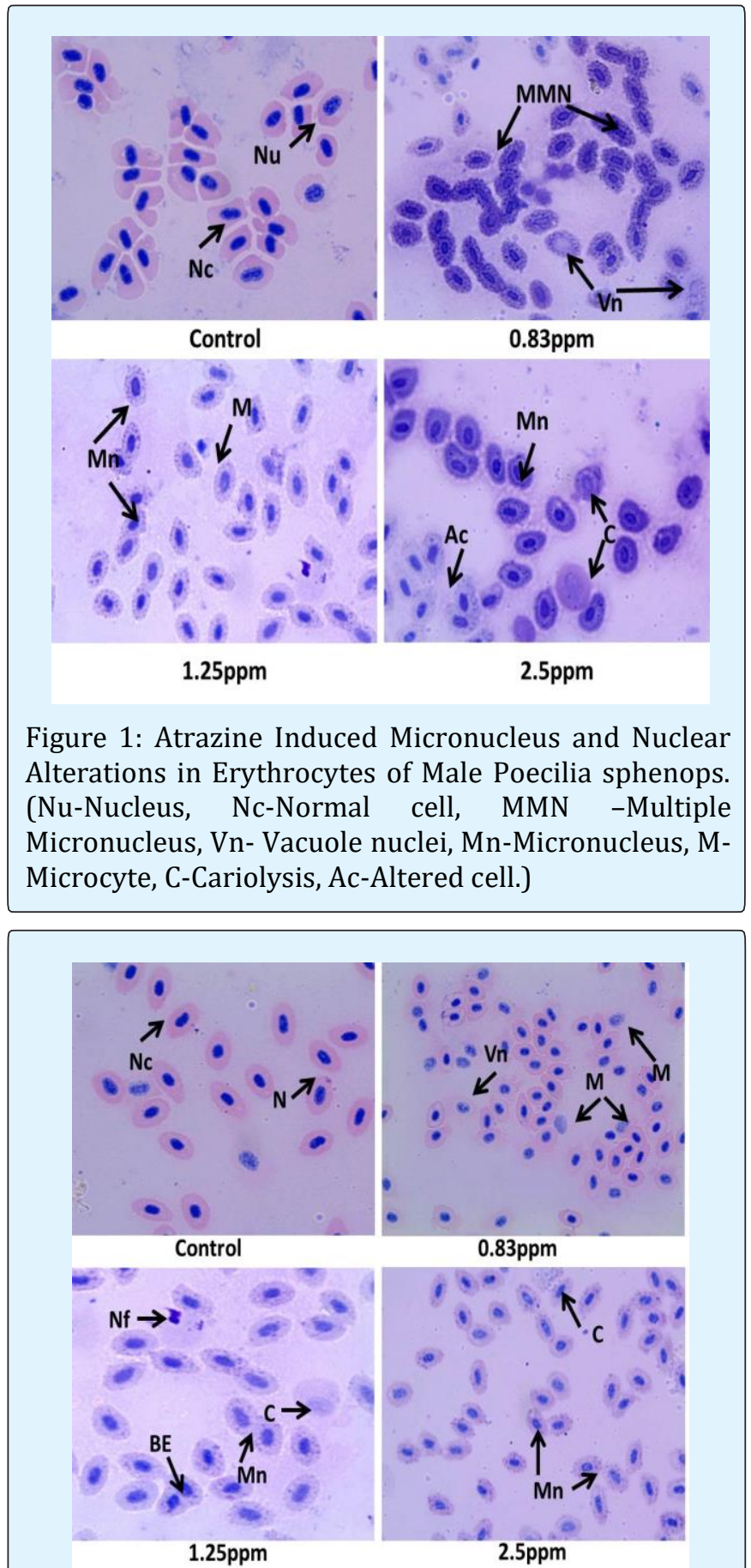

Figure 2: Atrazine Induced Micronucleus and Nuclear Alterations in Erythrocytes of Female Poecilia sphenops.(N-Nucleus, Nc- Normal cell, Vn- Vacuole nuclei, M-Microcyte, Nf-Nuclear fragmentation, Mn Micronucleus, BE-Binucleated Erythocytes, CCariolysis)

In this study, it is also investigated whether atrazineinduce DNA damage. After exposure of Poecilia sphenops with different concentrations of atrazine, liver cell DNA is isolated. This isolated DNA is run on $0.8 \%$ agarose gel and the photograph is taken under UV light. As shown in Figure $3 \& 4$, chromosomal DNA is detected on the upper portion of the gel in control fish sample. The results predict that DNA fragmentation patterns are detected in DNA extracted from cells treated with atrazine, but no DNA fragmentation are detected in controls.

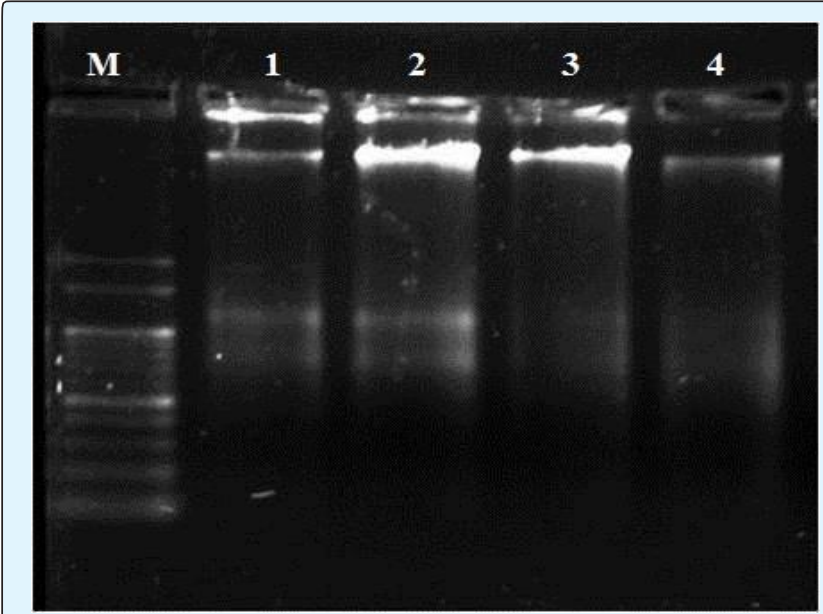

Poecilia sphenops. (M- DNA Ladder 1000bp, 12.5ppm, 2-1.25ppm, 3- 0.83ppm, 4- Control.)

Figure 3: Atrazine induced DNA Fragmentation in Liver of Male.

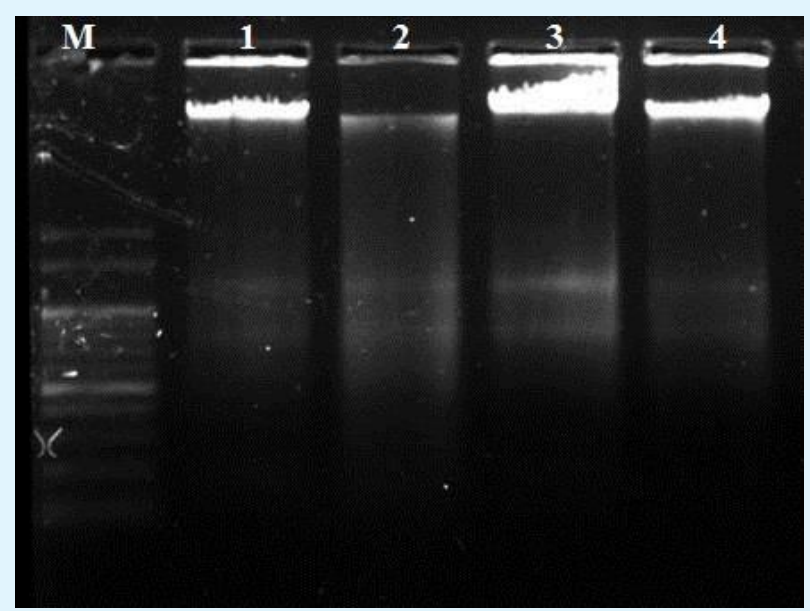

Poecilia sphenops. (M- DNA Ladder $1000 \mathrm{bp}, 1$ - 2.5ppm, 2-1.25ppm, 3- 0.83ppm, 4- Control.)

Figure 4: Atrazine induced DNA Fragmentation in Liver of Female

\section{Discussion}

Molecular markers of the biological effects of contaminants on organisms (Biomarkers) can be used as diagnostic and prognostic early warning tests to detect and assess the effects of pollution, particularly 
low concentrations of complex mixtures of contaminants, on environmental quality [11]. In the present study, genotoxicity are evaluated through micronuclei and DNA fragmentation assay, for atrazine impact in Poecilia sphenops. Present results point out that the DNA damage in liver of Poecilia sphenops increases with increasing atrazine concentration, indicating that atrazine-induces DNA damage in Poecilia sphenops and the levels of micronuclei formation imposed by atrazine could be quantified by micronuclei assay.

Fragmentation of DNA in the form of a ladder due to endonucleolytic attack is reportedly considered as an apoptosis and DNA damage related event. DNA fragmentation was considered as one of the later steps in apoptotic program [12]. DNA ladder formation is observed in liver of Poecilia sphenops exposed to atrazine. The present study with Poecilia sphenops could confirm the genotoxicity of atrazine, which is evaluated by the evidence of fragmentation of the genetic material. These results support previous studies have evaluated the genotoxic effect of atrazine herbicides induce DNA fragmentation in different organisms [13,14]. Moreover, DNA fragmentation is evidenced in the present study by DNA gel electrophoresis in Atrazine treated Poecilia sphenops liver.

The toxicological effect of atrazine originates from its oxidizing action. Once entered in to the cell, in the presence of cellular reductants, it induces DNA fragmentation or DNA strands breakage, which is considered to be premutagenic change [15]. The DNA fragmentation or DNA strand breaks are also considered to be a kind of lesion that is potentially premutagenic; the production of breaks in the DNA strands being related to mutagenic and carcinogenic properties of chemicals $[16,15]$.

The main mechanism of action of Atrazine for the induction of cytotoxicity and genotoxicity is probably due to an increase of oxidative stress. There is an elevated DNA fragmentation in the liver of Poecilia sphenops, associated with increased ROS and the consequent oxidative stress due to atrazine which can be responsible for the observed DNA damage. These results support previous studies have evaluated the nanoparticles induce cellular damage through ROS production and also cause genetic damage. The DNA fragmentation in fish tissues evidence that nanoparticles induce DNA damage [17]. Further the genotoxicity effect of atrazine in Poecilia sphenops was confirmed by micronuclei studies. The micronucleus test in peripheral erythrocytes provides a possible approach to monitor the effects of environmental genotoxic agents in fish. The micronucleus assay in erythrocytes of fish was widely used as a marker for environment pollutant [18]. The pesticide cause significant damage in the red blood cells of Channa punctatus even at a lower concentration [19].

Genotoxicity of atrazine herbicide for all tested concentrations can be verified by the results which is significantly different from the control test. The highest concentration of atrazine (2.5ppm) exposed to Poecilia sphenops shows the highest rates of cells with micronuclei, indicating the high mutagenicity of the atrazine. The result of present studies suggests that there is high frequency of micronuclei and nuclear abnormalities in Poecilia sphenops exposed to the different concentrations of atrazine. It also observed that atrazine induce high rate of micronuclei frequency and nuclear abnormalities in Oreochromis niloticus [20]. A study reported that commercial formulation of atrazine treatment significantly induces micronucleus formation in Carassius auratus [21].

\section{Conclusion}

The finding of the present study demonstrates that Atrazine herbicide possess DNA damaging potential in Poecilia sphenops. DNA fragmentation and the micronucleus test as genotoxicity endpoints and reported significant increases in the frequencies of both micronuclei and DNA fragments following exposure to atrazine. These findings may provide evidence for atrazine induced genotoxicity that could be useful for investigating the effects of toxic blooms on wild fish populations.

\section{References}

1. Zeljezic D, Garaj-Vrhovac V, Perkovic P (2006) Evaluation of DNA damage induced by atrazine and atrazine-based herbicide in human lymphocytes In vitro using a comet and DNA diffusion assay. Toxicol in Vitro 20(6): 923-935.

2. Singh M, Kaur P, Sandhir R, Kiran R (2008) Protective effects of vitamin E against atrazineinduced genotoxicity in rats. Mutat Res 654(2): 145-149.

3. Amado LL, Robaldo RB, Geracitano L, Monserrat JM, Bianchini A (2006) Biomarkers of exposure and effect in the Brazilian flounder Paralichthys orbignyanus (Teleostei: Paralichthyidae) from the Patos Lagoon estuary (Southern Brazil). Mar Pollut Bull 52(2): 207-213.

4. Datta S, Saha DR, Ghosh D, Majumdar T, Bhattacharya S, et al. (2007) Sub-lethal 
concentration of arsenic interferes with the proliferation of hepatocytes and induces in vivo apoptosis in Clarias batrachus L. Comp Biochem Physiol C Toxicol Pharmacol 145(3): 339-349.

5. Akaoa Y, Nakagawa Y, Akiyama K (1999) Arsenic trioxide induces apoptosis in neuroblastoma cell lines through the activation of caspase 3 in vitro. FEBS Lett 455(1-2): 59-62.

6. Wolf HD, Blust R, Backeljau T (2004) The population genetic structure of Littorina littorea (Mollusca: Gastropoda) along a pollution gradient in the Scheldt estuary (The Netherlands) using RAPD analysis. Sci Total Environ 325(1-3): 59-69.

7. Gustavino B, Scornajenghi KA, Minissi S, Ciccotti E (2001) Micronuclei induced in erythrocytes of Cyprinus carpio (telostei, pisces) by X-rays and colchicine. Mutat Res 494(1-2): 151-159.

8. Vasanth S, Subramanian P (2016) Assessment of Genotoxic Effect of Atrazine on Poecilia Sphenops Using Micronucleus Assay. Int J Chem Pharm Sci 4(6): 293-295.

9. Carrasco KR, Tilbury KL, Mayers MS (1990) Assessment of the piscine micronuclei test as an in situ biological indicator of chemical contaminants effects. Can J Fish Aquat Sci 47: 2123-2136.

10. Sambrook J, Fritsch EF, Maniatis T (1989) Molecular Cloning. A Laboratory Manual, 2 ${ }^{\text {nd }}$ (Edn.), Cold Spring Harbor Laboratory Press, Cold Spring Harbor, NY.

11. Livingstone DR (1993) Biotechnology and pollution monitoring - use of molecular biomarkers in the aquatic environment. J Chem Technol Biotechnol 57(3): 195-211.

12. Hickey EJ, Raje RR, Reid VE, Gross SM, Ray SD (2001) Diclofenac induced in vivo nephrotoxicity may involve oxidative stress-mediated massive genomic DNA fragmentation and apoptotic cell death. Free Radic Biol Med 31(2): 139-152.

13. Tennant AH, Peng B, Kligerman AD (2001) Genotoxicity studies of there triazine herbicides: In vivo studies using the alkaline single cell gel (SCG) assay. Mutat Res 493(1-2): 1-10.

14. Garaj-Vrhovac V, Zeljezic D (2002) Assessment of genomic damage in a population of Croatian workers employed in pesticide production by chromosomal aberration analysis, micronucleus assay and Comet assay. J Appl Toxicol 22(4): 249255.

15. Kammann U, Bunke M, Steinhart H, Theobald N (2001) A perma-nent fish cell line (EPC) for genotoxicity testing of marine sedi-ments with the comet assay. Mutat Res 498(1-2): 67-77.

16. Frenzilli G, Bosco E, Barale R (2000) Validation of single gel assay in human leukocytes with 18 reference compounds. Mutat Res 468(2): 93-108.

17. Ramesh R, Kavitha P, Kanipandian N, Arun S, Thirumurugan R, et al. (2013) Alteration of antioxidant enzymes and impairment of DNA in the SiO2 nanoparticles exposed zebra fish (Danio rerio). Environ Monit Assess 185(7): 5873-5881.

18. Gustavino B, Scornajenghi KA, Minissi S, Ciccotti E (2001) Micronuclei induced in erythrocytes of Cyprinus carpio (telostei, pisces) by X-rays and colchicine. Mutat Res 494: 151-159.

19. Sawhney AK, Johal MS (2000) Erythrocyte alterations induced by malathion in Channa punctatus (Bloch). Bull Environ Contam Toxicol 64(3): 398-405.

20. Campos-Ventura B, De-Angelis DF, Marin-Morales MA (2008) Mutagenic and genotoxic effects of the atrazine herbicide in Oreochromis niloticus (Perciformes, Cichlidae) detected by the micronuclei test and the comet assay. Pesticide Biochem Physiol 90: 42-51.

21. Cavas T, Ergene-Gozukara S (2003) Micronuclei, nuclear lesions and interphase silver-stained nucleolar organizer regions (AgNORs) as cytogenotoxicity indicators in Oreochromis niloticus exposed to textile mill effluent. Mutat Res 538(1-2): 81-91.

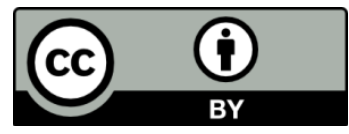

